\title{
TAXONOMIC REPORTS OF HOMEACANTHOIDEA (EUCESTODA: TRYPANORHYNCHA) IN LAMNID AND SPHYRNID ELASMOBRANCHS COLLECTED OFF THE COAST of Santa Catarina, Brazil
}

\author{
GOMES D.C.*, KNOFF M.*, SÃO CLEMENTE S.C.**, LANFREDI R.M.**** \& PINTO R.M.*
}

Summary:

Elasmobranch specimens of lamnid and sphyrnid captured in 1999 in the State of Santa Catarina, Brazil, were parasitized with homeacanthoid trypanorhynch cestodes: Isurus oxyrinchus Rafinesque, 1810 with Nybelinia lingualis (Cuvier, 1817) Dollfus, 1929; Sphyrna zygaena (Linnaeus, 1758) with Heteronybelinia rougetcampanae (Dollfus, 1960) Palm, 1999. New details of internal morphology and/or scolex and/or proglottid surface ultrastructure are given. Adults of $N$. lingualis are reported for the first time in the Brazilian coast.

KEY WORDS : Eucestoda, Trypanorhyncha, Homeacanthoidea, elasmobranchs, Brazil.

\section{INTRODUCTION}

$\mathrm{D}$ uring an extensive parasitological survey, numerous specimens of parasites were collected from 90 elasmobranch fishes of the Southern coast off Brazil. Recently, several taxonomic and parasitological indices on elasmobranch parasites of Brazil have been published on nematodes (Knoff et al., 2001a), on digeneans and acanthocephalans (Knoff et al., 2001b), on prevalences and intensities of infections of trypanorhynch cestodes (Knoff et al., 2002), and on otobothrioid trypanorhynch cestodes (Knoff et al., 2004). The present paper continues this study and relates to Homeacanthoidea (Eucestoda, Trypanorhyncha) recovered from Lamnidae and Sphyrnidae.

\footnotetext{
* Laboratório de Helmintos Parasitos de Vertebrados, Departamento de Helmintologia, Instituto Oswaldo Cruz, Avenida Brasil 4365, 21040-900 Rio de Janeiro, Brazil.

** Faculdade de Veterinária, Universidade Federal Fluminense, Niterói, Rio de Janeiro, Brazil.

*** Laboratório de Biologia de Helmintos Otto Wucherer, Instituto de Biofísica Carlos Chagas Filho, Universidade Federal do Rio de Janeiro, Brazil.

Correspondence : Delir Corrêa Gomes.

Tel. : + 502125984362 extension-130

Fax. : + 502125984362 extension-132

E-mail : dcgomes@ioc.fiocruz.br
}

Résumé : OBSERVATIONS TAXONOMIQUES D'HOMEACANTHOIDEA (EuCESTODA: TRYPANORHYNCHA) CHEZ LES ÉLASMOBRANCHES LAMNIDES ET SPHYRNides RÉCOlTÉS SUR la CÔTE DE SANTA CATARINa, BréSIL

Des spécimens d'élasmobranches lamnides et sphyrnides capturés en 1999 dans l'État de Santa Catarina, Brésil, étaient parasités par des cestodes trypanorhynches, homéacanthes: Isurus oxyrinchus Rafinesque, 1810 avec Nybelinia lingualis (Cuvier, 1817) Dollfus, 1929; Sphyrna zygaena (Linnaeus, 1758) avec Heteronybelinia rougetcampanae (Dollfus, 1960) Palm, 1999. De nouveaux détails de la morphologie interne et/ou de l'ultrastructure du scolex et/ou des proglottides sont fournis. Pour la première fois, des adultes de N. lingualis sont signalés sur la côte brésilienne.

MOTS CLÉS : Eucestoda, Trypanorhyncha, Homeacanthoidea, élasmobranches, Brésil.

Nybelinia lingualis (Cuvier, 1817) Dollfus, 1929, parasitizing the spiral valve of Isurus oxyrinchus Rafinesque, 1810, had already been reported from the spiral valves of Mustelus asterias Cloquet, 1821 in Mauritania (Dollfus, 1942), Carcharhinus leucas (Müller \& Henle, 1839) in Texas, USA (Henson, 1975) and I. oxyrinchus in Spain (Gómez Cabrera, 1990). This species has also been reported from several teleosts and cephalopods from the Mediterranean and Atlantic Ocean (North, Tropical and South) (Dollfus, 1942, 1958; Bates, 1990; Orts et al., 1988; Anato et al., 1991; Sewell \& Lester, 1995; Costa et al., 1996; Tanzola et al., 1997; Schuhgalter, 1998). Recently, Palm (1999), examined unidentified specimens deposited in the British Museum of Natural History, and expanded the known the range of $N$. lingualis in teleosts to Adelaide, Australia and English Channel. Previous reports of plerocercoids of this species in Brazil were those of Mendes (1944) in Cynoscion sp. in the littoral waters of Santos, State of São Paulo, Saciloto (1980), in Cynoscion leiarchus (Cuvier, 1830) off the State of Paraná, São Clemente \& Gomes (1989), from the spiral valve of Mustelus canis (Mitchill, 1815) in waters off the State of Rio Grande do Sul and by Palm (1997) from the abdominal cavity of Carangidae, Haemulidae and Mullidae teleost fishes, captured in the vicinity of Recife, State of Pernambuco.

Heteronybelinia rougetcampanae (Dollfus, 1960) Palm, 1999, from the spiral valve of Sphyrna zygaena (Lin- 
naeus, 1758) was originally described on the basis of a single plerocercoid collected from the teleost Liosaccus cutaneus from Dakar, Senegal (Dollfus, 1960). It has subsequently been reported from the teleost Hoplostethus mediterraneus (Val., 1928) (= H. mediterraneus Cuvier, 1829) in the eastern Mediterranean (Reimer, 1975) and by Pereira Jr. (1998) in sciaenid fishes from the littoral region of the State of Rio Grande do Sul, with the addition of the new hosts, Menticirrus americanus (Linnaeus, 1758) and Umbrina canosai Berg, 1895. Adults of the species were described on the basis of specimens recovered from Sphyrna lewini also off the State of Rio Grande do Sul (São Clemente \& Gomes, 1992).

\section{MATERIALS AND METHODS}

$\tau$ n March 1999, nine elasmobranchs, four females of Isurus oxyrinchus, $165-221 \mathrm{~cm}$ in total length (tl), and five specimens (one male, four females) of Sphyrna zygaena, $190-250 \mathrm{~cm}$ tl, were caught about 190 miles off the coast of the State of Santa Catarina (27 08' S - $28^{\circ} 38^{\prime} \mathrm{S}$; $\left.45^{\circ} 30^{\prime} \mathrm{W}-46^{\circ} 53^{\prime} \mathrm{W}\right)$ in waters approximately $25 \mathrm{~m}$ in depth by professional fishermen of the Kiyomã tuna fishing vessel. On board, spiral valves were collected, labelled and placed on ice before examination. Cestodes alive and dead were recovered, fixed, stained and mounted according to the technique of Amato et al. (1991). Taxonomic classification is in accordance with Campbell and Beveridge (1994) and Palm (1999) for superfamily and generic levels, respectively. Synonymy of Nybelinia lingualis is not provided, as it is available in detail in Dollfus (1942). Synonymy is provided for Heteronybelinia rougetcampanae, which was not treated in Dollfus (1942). Scolex, hooks and segment measurements and terminology follow Dollfus (1942), Campbell \& Beveridge (1994) and Palm (1999), and the terminology of metacestodes follows Chervy (2002). Measurements are in millimeters $(\mathrm{mm})$ unless otherwise indicated as means followed by the range of variation in parentheses. In the taxonomic summaries, the total number of parasitized specimens and the infrapopulation of each host are indicated. NH refers to new hosts; drawings were made with the aid of a drawing tube connected to a brightfield Olympus BH-2 light microscope (LM). Some specimens were observed under a LEO 435 Variable Pressure Scanning Electron Microscope (VPSEM); other samples were routinely prepared and analyzed with a JEOL Scanning Electron Microscope (SEM). Representative specimens have been deposited in the Coleção Helmintológica do Instituto Oswaldo Cruz, Rio de Janeiro, Brazil (CHIOC); samples for comparison were also obtained from the CHIOC. At least one host spe- cimen of each investigated fish species was deposited as a symbiotype sensu Brooks (1993) in the collection of the Instituto de Pesca, Santos, SP, Brazil and listed by Knoff et al. (2001b).

\section{RESULTS}

\author{
Homeacanthoidea Dollfus, 1942 \\ Tentaculariidae Poche, 1926 \\ NYBELINIA POCHE, 1926 \\ NYBELINIA LINGUALIS
}

(Cuvier, 1817) Dollfus, 1929 (Figs 1-9)

$\mathrm{D}$

escription based in 18 adults, 10 mounted and measured, two under VPSEM and six under SEM. Scolex acraspedote, sub-cylindrical 1.90 (1.24-2.36) long, including velum, widest at level of pars bothridialis, $0.93(0.47-1.20)$. Pars bothridialis 1.04 (0.80-1.38) long, $0.92(0.47-0.20)$ wide. In some of the specimens preserved as whole mounts, among grooves near and mainly in distal margins of bothridia, hooklike microtriches, were detected (confirmed by SEM). Pars vaginalis with sheaths slightly sinuous, sometimes straight, 0.83 (0.53-1.07) long. Pars bulbosa 0.37 (0.30$0.54)$ long, $0.42(0.29-0.50)$ wide. Individual bulbs 0.35 (0.29-0.42) long, 0.13 (0.09-0.15) wide. Origin of retractor muscle at botton of bulbar cavity. Pars postbulbosa short, 0.06 long. Velum well developed, 0.54 (0.28-0.76) long. Diameter of unarmed tentacles : basal region 0.037 (0.020-0.044), metabasal region 0.030 (0.020-0.034). Tentacular armature homeoacanthous; hooks solid, homeomorphous. Hooks of external face of basal region 0.009 (0.007-0.011) long, base 0.009 (0.006-0.010) wide. At beginning of external face of the metabasal region, hooks 0.011 (0.009-0.013) long, base $0.010(0.009-0.011)$ wide. Hooks at apical region of external metabasal region 0.015 (0.013-0.017) long, base 0.013 (0.011-0.014) wide. Number of hooks per row in basal region 12-14, 16-20 per row near apical end. Tentacles partially everted, up to the $41^{\text {st }}$ row. Strobila anapolytic, maximum length 16, with numerous proglottids, most wider than long, largest proglottid 33.6 long/wide. Mature proglottids acraspedote, 0.24 long, 0.40 wide. Terminal proglottids slightly longer than wide. Vas deferens coiled, anterior to cirrus pouch, somewhat median, in anterior $1 / 4$ of proglottid. Cirrus pouch tubular, directed antero-medially, reaching middle of proglottid, 0.080 long, 0.024 wide. Genital pores ventral, irregularly alternate, pre-equatorial, sub-marginal. Testes 180-210 in number, rounded, 0.016-0.020 in diameter, occupying almost entire intervascular region of segment, including postovarian region. Ovary with four lobes in transverse view, bi-lobed in dorso-ventral views, separated by a 

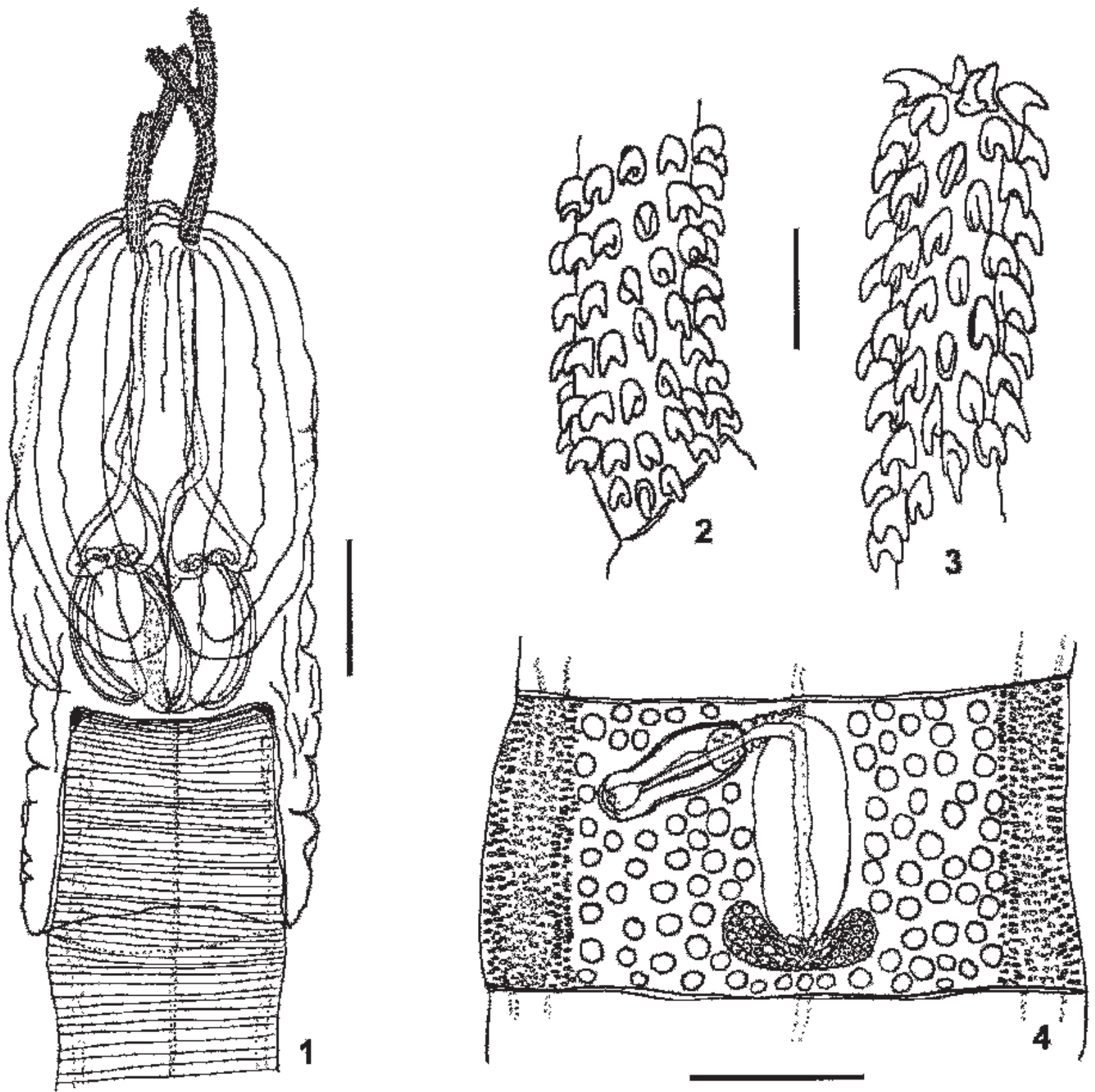

Figs 1-4. - Nybelinia lingualis. 1. Scolex. 2. Tentacle, basal region, bothridial face. 3. Tentacle, metabasal region, bothridial face. 4. Mature proglottid, ventral view. Bars of figs: $1=0.25 \mathrm{~mm} ; 2-3=0.025 \mathrm{~mm} ; 4=0.125 \mathrm{~mm}$.

few testes from posterior region of proglottid; ovaries 0.024 long, 0.080 wide. Mehlis gland ventral to ovarian isthmus. Uterus saccate reaching near anterior extremity of proglottid. Uterine pore conspicuous in youngest proglottids. Median groove at junction of proglottids at site of origin of uterine pore. Vagina runs along posterior margin of cirrus pouch, opening at genital atrium. Vitellaria follicular circumcortical, extending throughout the length of proglottid, sometimes laterally surpassing osmoregulatory canals. Eggs not observed.
Host/site of infection: 27 adults $(1 ; 2 ; 5 ; 19)$ from the spiral valves of four females of Isurus oxyrinchus.

Locality: coast of the State of Santa Catarina, Brazil.

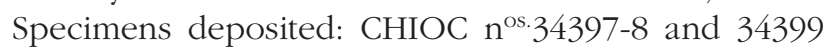
a-d.

Material examined: Plerocercoid, from Mustelus canis, Rio Grande do Sul, Brazil (CHIOC n³2568).

Remarks: the reported specimens are in agreement with previous descriptions (Dollfus, 1942; São Clemente \& Gomes, 1989; Palm, 1999). The measurements of the scolex length and the hooks of the basal 

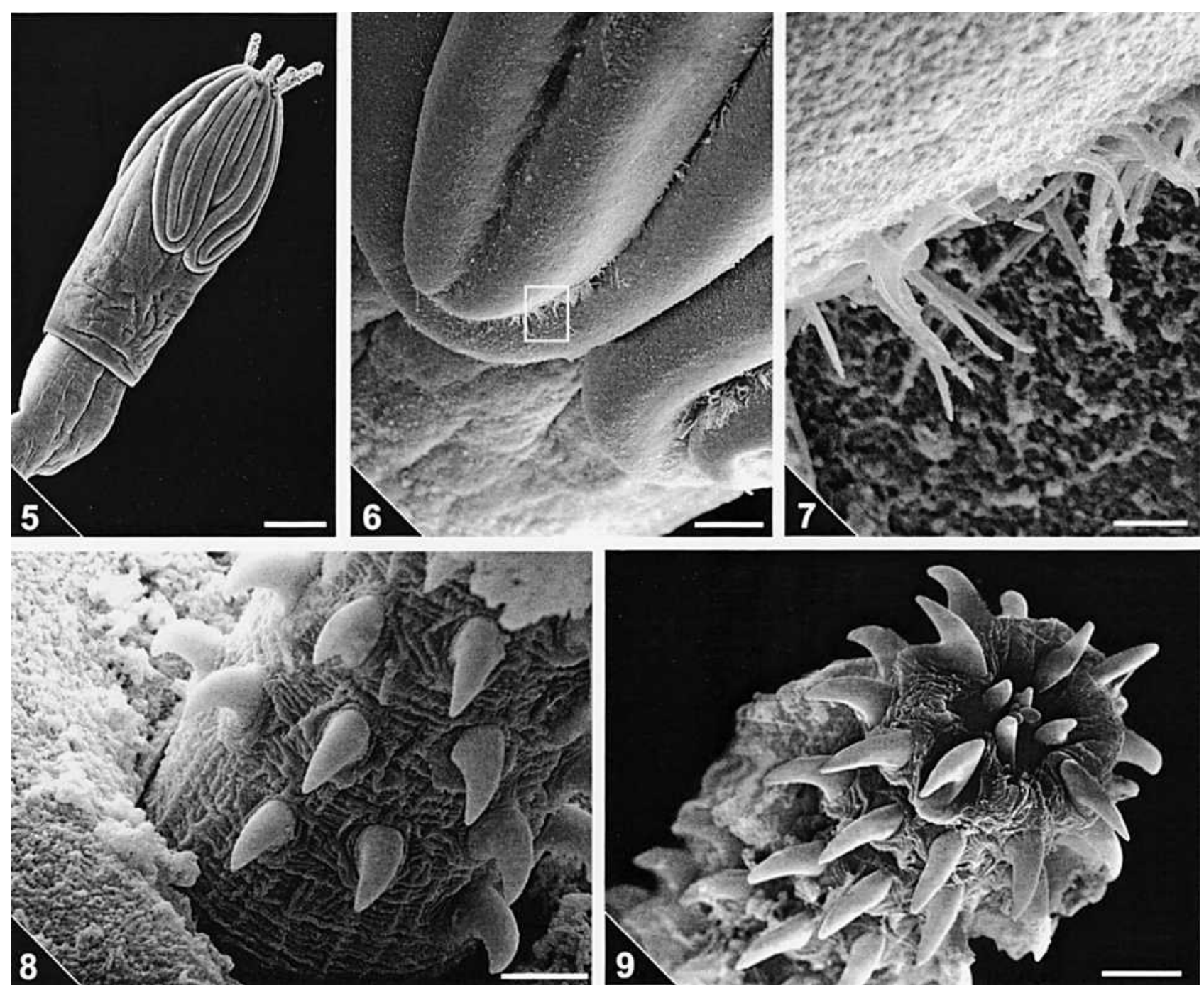

Figs 5-9. - Nybelinia lingualis, SEM. 5. Scolex. 6. Distal bothridial region, showing hook-like microthriches along the grooves near bothridial margins. Rectangle indicates region from which fig. 7 was obtained. 7. Hook-like microthriches along the grooves near bothridial margins. 8. Tentacle, basal region, external face. 9. Tentacle, metabasal region, external face. Bars of figs $5=250 \mu \mathrm{m} ; 6=40 \mu \mathrm{m} ; 7=4 \mu \mathrm{m}$; $8=9 \mu \mathrm{m} ; 9=10 \mu \mathrm{m}$.

and metabasal regions are smaller when compared to those obtained by Dollfus (1942), but are comparable with the data of São Clemente \& Gomes (1989) and Palm (1999). Also, the format of the scolex and the pattern of the tentacular hooks are in accordance with the figures of $N$. lingualis. According to Dollfus (1942), specimens of this species posses remarkably short bulbs and the tentacular sheaths make 1-2 coils near the bulbs, as also observed by São Clemente \& Gomes (1989) and Palm (1999). The pars bothridialis, in its varying extension partially covers a small portion of the pars bulbosa at its the anterior region or may extend to its middle. Dollfus (1942) stated that this species varies in the length of the scolex and of the pars bothridialis in different hosts. Specimens of $N$. lingualis observed with LM and SEM, have hooklike microtriches in the grooves near the bothridial margins; also the surface of the scolex possesses refringent filiform microtriches, as described for $T$. coryphaenae, N. queenslandensis and $N$. lingualis (Palm, 1995, 2000; Jones \& Beveridge, 1998). Adults of $N$. lingualis have been collected in Spain from Isurus oxyrinchus by Gómez Cabrera (1990), and this is the first report of the adult form of the species from specimens captured in the Brazilian littoral waters. This report further confirms that $T$. coryphaenae and N. lingualis have a wide geographical distribution and low host specificity. 
HeTERONyBelinia PALM, 1999 HETERONYBELINIA ROUGETCAMPANAE

(Dollfus, 1960) Palm, 1999 (Figs 10-16) SYNONYM:

NYBELINIA ROUGETCAMPANAE DOLLFUS, 1960

Description based on three plerocercoids uncompressed, two mounted and measured and one observed with SEM. Scolex subcylindrical, 1.66 (1.641.68) long, greatest width of scolex at level of pars bothridialis $0.62(0.52-0.62)$ (including velum without appendix). Pars bothridialis 0.835 (0.83-0.84) long,
$0.62(0.52-0.72)$ wide. Pars vaginalis with sinuous tentacle sheaths, 0.89 (0.85-0.93) long. Pars bulbosa 0.71 (0.65-0.77) long, 0.35 (0.34-0.42) wide. Individual bulbs 0.65 (0.60-0.76) long, $0.135(0.13-0.14)$ wide. Pars postbulbosa 0.15 (0.14-0.16) long. Appendix 0.17 (0.10$0.24)$ long. Velum 0.105 (0.09-0.12) long. Diameter of unarmed tentacles: basal region 0.086 (0.080-0.096); metabasal region 0.081 (0.076-0.092). Tentacular armature homeoacanthous, hooks heteromorphous. Hooks of basal region, $1^{\text {st }}$ and $2^{\text {nd }}$ rows: bothridial hooks longer and with less prominent curvature, 0.022 long, 0.014 wide; antibothridial hooks shorter and uncinate,
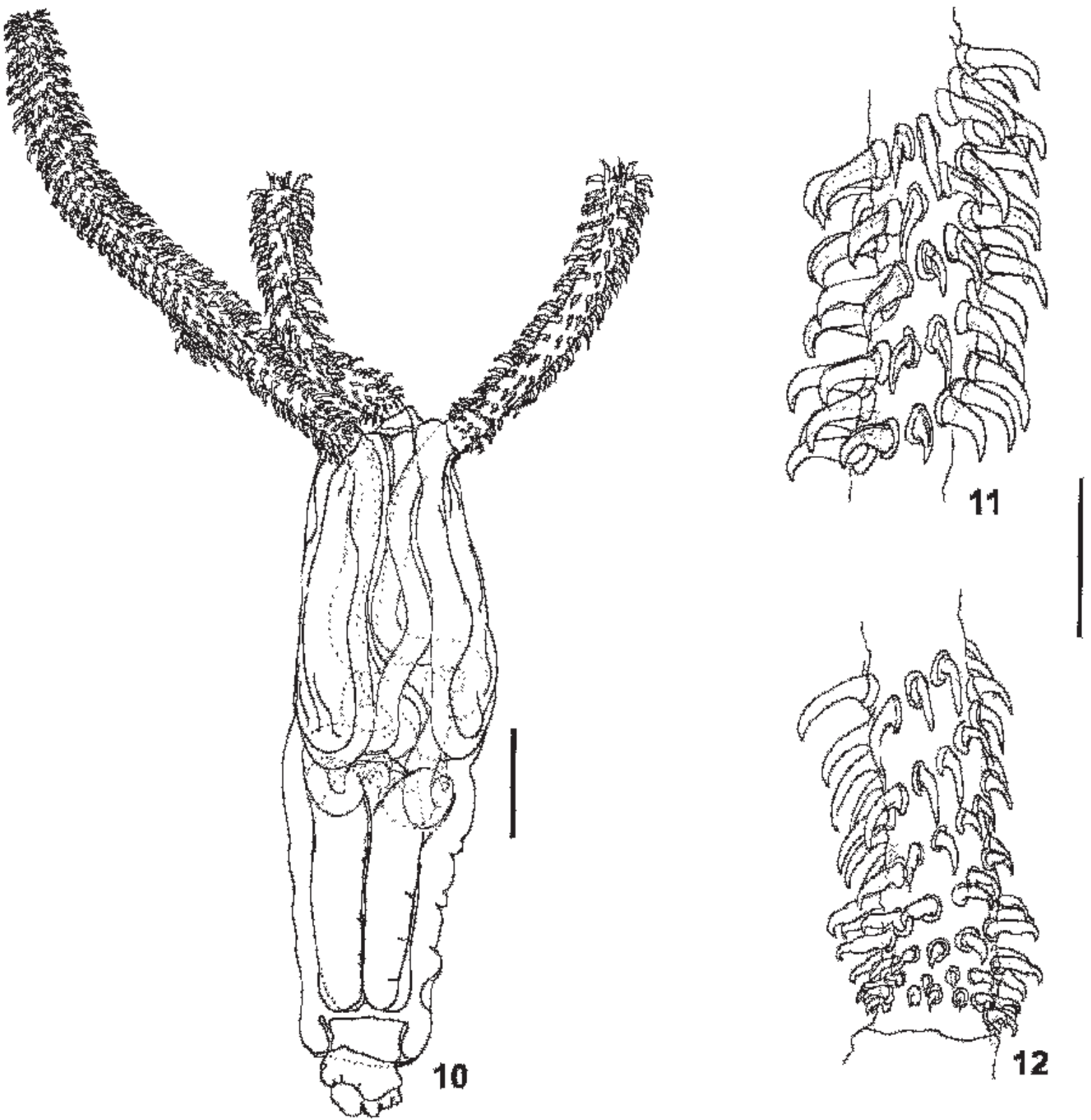

Figs 10-12. - Heteronybelinia rougetcampanae. 10. Scolex. 11. Tentacle, metabasal region, external face. 12. Tentacle, basal region, external face. Bars of figs: $10=0,25 \mathrm{~mm} ; 11-12=0,1 \mathrm{~mm}$. 

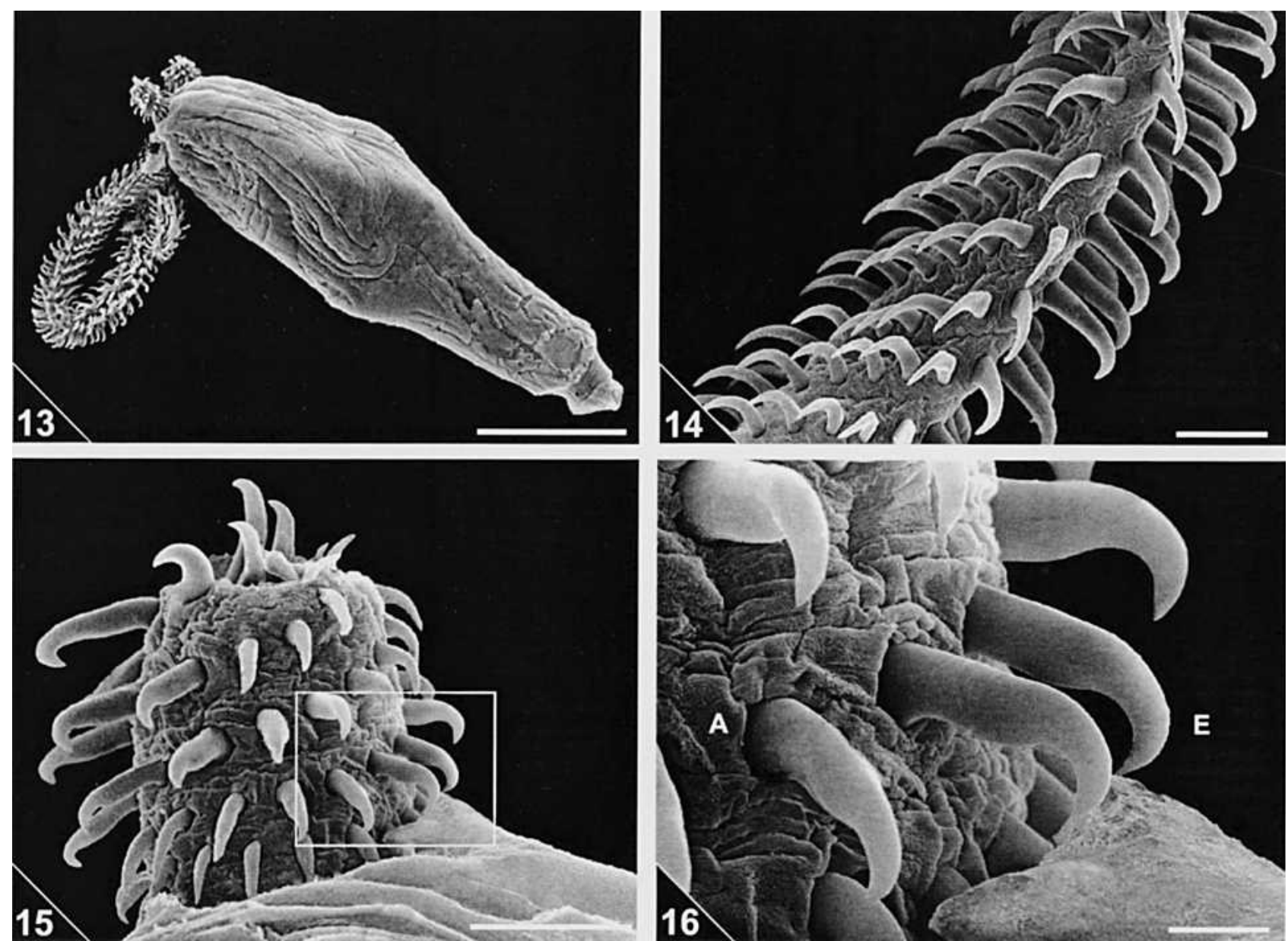

Figs 13-16. - Heteronybelinia rougetcampanae, SEM. 13. Scolex. 14. Tentacle, metabasal region, external face. 15. Tentacle, basal region, antibothridial face. Rectangle indicates region from which fig. 16 was obtained. 16. Details of bill-hooks on the basal region, two bill-hooks of antibothridial face (A) and three of external face (E). Bars of figs: $13=500 \mu \mathrm{m} ; 14-15=50 \mu \mathrm{m} ; 16=10 \mu \mathrm{m}$.

0.016-0.018 long, 0.012-0.013 wide; in the $3^{\text {rd }}$ row, characteristic bill-hooks present; arrangement persists to $6^{\text {th }}$ row; bothridial hooks long with less prominent curvature, 0.036-0.042 long, 0.014-0.018 wide; antibothridial hooks uncinate, 0.028-0.030 long, 0.011-0.012 wide; $4^{\text {th }}$ and $5^{\text {th }}$ rows: bothridial hooks, tip of hooks directed downwards in an angle of $90^{\circ}, 0.052-0.058$ long, 0.016-0.020 wide; antibothridial hooks with less prominent curvature, 0.026-0.036 long, 0.012-0.014 wide; $6^{\text {th }}$ row: bothridial hooks similar to those of $4^{\text {th }}$ and $5^{\text {th }}$ rows but straighter, 0.058 long, 0.020 wide; antibothridial hooks with very curved tips, 0.036 long, 0.014 wide. Hooks of metabasal region loose characteristic bill-hooks format, $7^{\text {th }}$ and $8^{\text {th }}$ rows: beginning of metabasal region bothridial hooks 0.060-0.066 long, 0.016-0.020 wide, antibothridial hooks 0.038-0.040 long, $0.014-0.016$ wide; $12^{\text {th }}$ and $13^{\text {th }}$ rows: bothridial hooks 0.060-0.064 long, 0.016-0.028 wide, antibothridial 0.0480.050 long, 0.024-0.026 wide. Apical rows, near the $45^{\text {th }}-46^{\text {th }}$ rows, hooks tend to become shorter: bothri- dial hooks 0.044 long, 0.016-0.018 wide, antibothridial hooks 0.034 long, 0.012 wide. Metabasal tentacular armature on antibothridial face presents stouter and more markedly curved hooks, with wide basis; on bothridial face, tentacular armature consists of more slender hooks, slightly curved at distal end and with stout base, loosing characteristic bill-hooks shape. Number of hooks/row, 12-14.

Host/site of infection: three plerocercoids from the spiral valve of one female of Sphyrna zygaena $(\mathrm{NH})$. Locality: coast of the State of Santa Catarina, Brazil. Specimen deposited: CHIOC $\mathrm{n}^{\mathrm{0}} 34500$.

Material examined: adults, from Sphyrna lewini, Rio

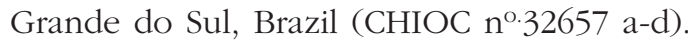

Remarks: the three plerocercoids recovered from S. zygaena in the littoral region of Santa Catarina, are larger compared to the original description on the basis of specimens obtained from L. cutaneous, from Dakar, Senegal (Dollfus, 1960). Nevertheless, the dimensions are closer to those reported by the latter author than 
those presented either by São Clemente \& Gomes (1992), on the basis of adults recovered from S. lewini or postlarvae collected in $M$. americanus and $U$. canosai (Pereira Jr., 1998), from the State of Rio Grande do Sul, Brazil. Dimensions of the structures of the scolex are also similar to those of the original description, except for the diameter of the tentacles which is twice as large in the basal and metabasal regions. In addition, the range of variation was larger in the basal, metabasal and distal hooks, in spite of the characteristic armatures. In the specimen examined under LM and SEM, microtriches were absent both on the scolex surface and in the grooves of the bothridial margins, in disagreement with data of Pereira Jr. (1998).

\section{ACKNOWLEDGEMENTS}

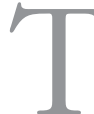
lo Dr Dely Noronha, Curator of the CHIOC, Rio de Janeiro, for the loan of voucher specimens. To Mr Bruno da Silva Vale, for the assistance at VPSEM from the Laboratório de Patologia do IOC, FIOCRUZ. To Mrs Heloisa Maria Nogueira Diniz, Mr Rodrigo Mexas and Mr Bruno Eschinazi da Silveira from the Laboratório de Produção e Processamento de Imagem Científica do IOC, FIOCRUZ, for figures processing. To Drs Alberto Ferreira Amorim and Carlos Alberto Arfelli, from the Instituto de Pesca de Santos, São Paulo, for the identification of the fishes, and also to the fishing boat Kiyomã from Santos for the help during capture of hosts. To Conselho Nacional para Desenvolvimento da Pesquisa - CNPq and Fundação Amparo à Pesquisa do Estado do Rio de Janeiro FAPERJ, for the partial financial support.

\section{REFERENCES}

Amato J.F.R., Boeger W.A. \& Amato S.B. Protocolos para Laboratório - Coleta e Processamento de Parasitos de Pescado. Imprensa Universitária, Universidade Federal Rural do Rio de Janeiro, Seropédica, 1991, 81p.

Anato C.B., KTaRi M.H. \& Dossou C. La parasitofaune métazoaire de Boops boops (Linné, 1758), poisson Téléostéen Sparidae des côtes tunisiennes. Oebalia, 1991, 17, 259-266.

BATES R.M. A Checklist of the Trypanorhyncha (Platyhelminthes: Cestoda) of the World (1935-1985). National Museum of Wales, Zoological Series No. 1, Cardiff, UK, 1990, 218 p.

BRooks D.R. Extending the symbiotype concept to host voucher specimens. Journal of Parasitology, 1993, 79, 631-633.

Campbell R.A. \& Beveridge I. Chapter 7. Order Trypanorhyncha Diesing, 1863, in: Keys to the cestode parasites of vertebrates. Khalil L.F., Bray R.A. \& Jones A. (eds.), CAB International, Cambridge, 1994, 51-148.

CHERvy L. The terminology of larval cestodes or metacestodes. Systematic Parasitology, 2002, 52, 1-33.
Costa G., Eiras J.C., Chubb J., Mackenzie K. \& Berland B. Parasites of black scabbard fish, Aphanopus carbo Lowe, 1839 from Madeira. Bulletin of the European Association of Fish Pathologists, 1996, 16, 13-16.

Dollfus R.P. Études critiques sur les tétrarhynques du Muséum de Paris. Archives du Muséum National d'Histoire Naturelle, Paris, 1942, 19, 1-466.

Dollfus R.P. Copépodes, Isopodes et Helminthes parasites de Céphalopodes de la Méditerrannée et de l'Atlantique Européen. Faune Marine des Pyrénées-Orientales, 1958, 6172.

Dollfus R.P. Sur une collection de Tétrarhynques homéacanthes de la famille de Tentaculariidae, récoltés principalement dans la région de Dakar. Bulletin de l'Institut Français d'Afrique Noire, 1960, 22, 788-852.

GÓmEz CABRERA S. Forma adulta de Nybelinia lingualis (Cuv., 1817) (Cestoda, Tentaculariidae) em Isuris oxyrhynchus Raf. (Pisces, Isuridae) del litoral español. Revista Ibérica de Parasitologia, 1990, 50, 51-52.

Henson R.N. Cestodes of elasmobranch fishes of Texas. Texas Journal of Science, 1975, 26, 401-406.

JONES M.K. \& BEVERIDGE I. Nybelinia queenslandensis sp. n. (Cestoda: Trypanorhyncha) in Carcharbinus melanopterus, from Australia, with observations on the fine structure of the scolex including the rhyncheal system. Folia Parasitologica, 1998, 45, 295-311.

Knoff M., São Clemente S.C., Pinto R.M. \& Gomes D.C. Nematodes of elasmobranch fishes from the southern coast of Brazil. Memórias do Instituto Oswaldo Cruz, 2001 a, 96, 81-87.

Knoff M., São Clemente S.C., Pinto R.M. \& Gomes D.C. Digenea and Acanthocephala of elasmobranch fishes from the southern coast of Brazil. Memórias do Instituto Oswaldo Cruz, 2001 b, 96, 1095-1101.

Knoff M., São Clemente S.C., Pinto R.M. \& Gomes D.C. Prevalência e intensidade de infecção de cestóides Trypanorhyncha de elasmobrânquios nos estados do Paraná e Santa Catarina, Brasil. Parasitologia Latinoamericana, 2002, 57, 149-157.

Knoff M., São Clemente S.C., Pinto R.M., Lanfredi R.M. \& GOMES D.C. Taxonomic reports of Otobothrioidea (Eucestoda, Trypanorhyncha) from elasmobranch fishes of the Southern coast off Brazil. Memórias do Instituto Oswaldo Cruz, 2004, 99, 31-36.

Mendes M.V. Sobre cestoda de teleósteos marinhos. Boletim da Faculdade de Filosofia, Ciências e Letras da Universidade São Paulo, Série Zoologia, 1944, 43, 173-184.

Orts E., Muñoz V., Fernández J.P. \& Carbonell E. Presencia de larvas de cestodos sobre Conger conger (L.) y Lophius piscatorius (L.) del litoral valenciano. Revista Iberica de Parasitologia, 1988, 48, 165-166.

PALM H.W. Untersuchungen zur Systematik von Rüsselbandwürmern (Cestoda: Trypanorhyncha) aus atlantischen Fischen. Berichte aus dem Institut für Meereskunde an der Christian Albrechts Universität, Kiel, 1995, 275, 1-238.

PaLM H.W. Trypanorhynch cestodes of commercial fishes from northeast Brazilian coastal waters. Memórias do Instituto Oswaldo Cruz, 1997, 92, 69-79. 
Palm H.W. Nybelinia Poche, 1926, Heteronybelinia gen. nov. and Myxonybelinia gen. nov. (Cestoda: Trypanorhyncha) in the collections of the Natural History Museum, London. Bulletin of the Natural History Museum, Zoology, 1999, 65, 133-153.

PaLm H.W. Trypanorhynch cestodes from Indonesian coastal waters (East Indian Ocean). Folia Parasitologica, 2000, 47, 123-124.

Pereira JR. J. Trypanorhyncha (Cercomeromorphae, Eucestoda) nos Scianidae (Neopterygii, Perciformes) do litoral do Rio Grande do Sul: sistemática, estrutura das comunidades componentes e sua utilização como indicadores da estrutura trófica da assembléia hospedeira, $\mathrm{PhD}$ Thesis, Universidade Federal do Paraná, Curitiba, Brasil, 1998, $243 \mathrm{p}$.

REIMER L.W. Helminthen von Fischen des Mesopelagials von Nordwestafrika. Wissenschaftliche Zeitschrift der Pädagogischen Hochschule "Liselotte Herrman" Güstrow, 1975, 2/75, 151-172.

SACILOTO M.P. Helmintofauna de Cynoscion leiarchus (Cuvier, 1830) (Pisces, Scianidae) de Matinhos, Paraná. MSc Thesis, Universidade Federal do Paraná, Curitiba, Brasil, 1980, $113 \mathrm{p}$.

SÃo ClemENTE S.C. \& GomES D.C. Trypanorhyncha from sharks of southern brazilian coast: Eutetrarhynchus vooremi sp. n. and two other species parasites of Mustelus (Pisces, Triakidae). Memórias do Instituto Oswaldo Cruz, 1989, 84, $475-$ 481.

SÃo Clemente S.C. \& Gomes D.C. Description of the adult form of Nybelinia (Syngenes) rougetcampanae Dollfus, 1960 and some new data on $N$. (N.) bisulcata (Linton, 1889) (Trypanorhyncha: Tentaculariidae). Memórias do Instituto Oswaldo Cruz, 1992, 87, 251-255.

SChuHgalter O.A. New data on the helminthfauna from the squid Sthenoteuthis pteropus (Cephalopoda: Ommastrephidae) [in Russian]. Parazitologiya, 1998, 32, 236-247.

SEwEll K.B. \& LeSTER R.J.C. Stock composition and movement of gemfish, Rexea solandri, as idicated by parasites. Canadian Journal of Fisheries and Aquatic Science, 1995, 52, 225-232.

Tanzola R.D., Guagliardo S.E., Brizzola M. \& ARias M.V. Helminth fauna of Porichthys porosissimus (Pisces Batrachoidiformes) in the estuary of Bahia Blanca Argentina. Helminthologia, 1997, 34, 221-227.

Reçu le 20 avril 2004

Accepté le 20 octobre 2004 